\title{
Social Investment, Employment and Policy and Institutional Complementarities: A Comparative Analysis across 26 OECD Countries
}

\author{
VINCENT BAKKER* (1D) AND OLAF VAN VLIET** \\ *Department of Economics, Leiden University, Leiden, the Netherlands \\ email:v.b.bakker@law.leidenuniv.nl \\ ** Department of Economics and Institute of Public Administration, Leiden University, \\ the Netherlands \\ email: o.p.van.vliet@law.leidenuniv.nl
}

\begin{abstract}
Raising employment has been at the heart of EU strategies for over twenty years. Social investment, by now a widely debated topic in the comparative welfare state literature, has been suggested as a way to pursue this. However, there are only a couple of systematic comparative analyses that focus on the employment outcomes associated with social investment. Analyses of the interdependence of these policies with regard to their outcomes are even more scarce. We empirically analyse the extent to which variation in employment rates within 26 OECD countries over the period 1990-2010 can be explained by effort on five social investment policies. We additionally explore the role of policy and institutional complementarities. Using time-series cross-section analyses we find robust evidence for a positive association between effort on ALMPs and employment rates. For other policies we obtain mixed results. ALMPs are the only policies for which we observe signs of policy interdependence, which point at diminishing marginal returns. Additionally, our analysis demonstrates that the interdependence of social investment policies varies across welfare state regimes. Together, this indicates that the employment outcomes of social investment policies are also contingent on the broader framework of welfare state policies and institutions.
\end{abstract}

Keywords: employment; social investment; policy complementarity; institutional complementarity; diminishing marginal returns; comparative welfare state analysis

JEL codes: $\mathrm{H}_{5} 3 ; \mathrm{I}_{3} 8 ; \mathrm{J}_{2} 1$

\section{Introduction}

For over twenty years, realising higher employment levels has been at the heart of EU strategies such as the Lisbon Strategy and Europe 2020. To realise the goals explicated in these strategies, the European Commission launched the Social Investment Package in 2013. In it, the Commission advocated a 'new 
approach' that involves "investing in social policies, services and cash benefits which both activate and enable" (2013: 10). Specifically, the Commission urged member states to "better reflect social investment in the allocation of resources [by] putting greater focus on policies such as (child)care, education, training, active labour market policies, housing support, rehabilitation and health services" (2013: 9). This approach is in line with the broader academic discourse on the sustainability of the welfare state, which describes the need of reorienting social policy towards programmes aimed at activation and human capital development to prepare individuals for the new social risks of the service-based economy (Taylor-Gooby, 2004; Armingeon and Bonoli, 2006).

Social investment has been presented as a promising strategy to reduce poverty and to realise economic growth. Since higher employment rates have been considered an important intermediate step to achieve these goals, social and labour market policies should be oriented at raising employment, possibly even at the expense of classical redistributive welfare state programmes (Van Vliet and Wang, 2015; Garritzmann et al., 2018; Van Vliet et al., 2021). In the social investment literature, it has been stressed that the outcomes of individual policies highly depend on their interdependence and the institutional context (Bouget et al., 2015; Hemerijck et al., 2016; Dräbing and Nelson, 2017). Remarkably, empirical insights into these interdependencies and this holistic perspective, regarding the effectiveness of social investment policies in general and with respect to employment outcomes in particular, are very limited. Hemerijck et al. (2016) is the only study that empirically examines the complementarity between two social investment policies. These authors employ an international comparative analysis in order to exploit the variance between, on the one hand, the interdependencies between social investment policies and, on the other hand, employment rates.

This study aims to complement the social investment literature by empirically analysing the association between effort on social investment policies and employment rates in 26 OECD countries over the period 1990-2010. In contrast to earlier comparative studies that analysed variation between countries namely, the extent to which expenditures on social investment are correlated with employment levels (Nelson and Stephens, 2012; Taylor-Gooby et al., 2015) - our study is focused on the developments within countries. Hence, we analyse associations between changes in effort on social investment policies and changes in employment rates within countries. This approach has also been used by Ahn and Kim (2015) and Hemerijck et al. (2016). With respect to these two studies, we seek to make three contributions. First, acknowledging the comprehensive perspective of the social investment literature on welfare states, we include a broader range of social investment policies. Second, this study extends the work on policy complementarities by Hemerijck et al. (2016) by also taking the institutional context into account. In line with holistic perspectives in the 
conceptual and theoretical social investment literature, we examine how policy complementarities are dependent on differences in broader configurations of welfare state institutions across countries. Third, we use more sophisticated measures of effort on social investment that account for demographic and economic conditions.

\section{Literature review and theory}

\subsection{The social investment state and social investment policies}

Throughout the 1990s, social investment arose as a product of new ideas regarding the role of social policy and its relation to the economy. Central to this notion of social investment is the idea that social policies can be seen as productive factors that generate positive returns to the economy by enhancing economic participation and realising economic growth (Midgley, 1999). This view is also reflected in more recent literature that defines the social investment state as "an institution that puts the emphasis less on income replacement and more on the promotion of labour market participation through activation and investment in human capital" (Bonoli and Natali, 2012: 9). Instead of offering a safety net through policies aimed at repairing damages after the occurrence of personal or economic crises, it provides a trampoline that involves policies aimed at preparing, supporting and equipping individuals to participate in the knowledge economy and respond to the new social risks associated with it (Morel et al., 2012). Accordingly, the social investment approach has been formulated in terms of reallocating expenditures on passive transfers to expenditures on activating and capacitating policies that invest in human capital and help make efficient use of it such as (early childhood) education, life-long learning, and active labour market policies (ALMPs) (Esping-Andersen, 2002; Morel et al., 2012).

These complementary functions of social investment can be linked to a variety of policies concerned with different stages of the life-course. Most empirical studies have concentrated on ALMPs and early childhood education and care (ECEC) exclusively (Bonoli, 2013; Hemerijck et al., 2016), although some have considered additional policies like education (Nelson and Stephens, 2012), parental leave, and life-long learning (Taylor-Gooby et al., 2015). Descriptive studies on the extent to which countries allocate resources to social investment tend to considerer an even broader range of policies and have also incorporated other family benefits, home-help and care for the elderly, and services for the incapacitated (Kvist, 2013; Kuitto, 2016; Ronchi, 2018). Guided by this literature we distinguish five groups of policies capable of mobilising the productive potential of individuals: ALMPs, early childhood policies, services for the elderly and frail, education, and maternity and parental leave. 


\subsection{Social investment policies and employment}

Employment outcomes are a function of the demand for and the supply of labour. Social investment can be characterised as a supply-side approach to social policy, which aims to increase the quantity and quality of employment through activation and human capital development. The employment effects associated with different social investment policies can, however, be expected to differ as they are targeted at different groups of society and operate through different mechanisms.

ALMPs concern a first type of social investment policy. Policies considered ALMPs differ in the extent to which they invest in human capital and stimulate employment through the labour market (Bonoli, 2010). Policies that score high on these dimensions and thereby clearly reflect social investment aspects are placement services, counselling, job-search programmes and training. Based on an extensive meta-analysis, Card et al. (2017) conclude that programmes offering job search assistance are associated with positive short term impacts, whereas the positive effects of programmes focused on human capital development manifest themselves in the years following completion of the programme. While the positive effects of most programmes tend to be the largest for women and the long-term unemployed, ALMPs can be considered a particularly effective social investment policy because of the large number of people that participate in these programmes.

Especially in the context of new social risks associated with increased female employment, the literature on social investment has discussed the relevance of policies that enable the reconciliation of work and family life (Plavgo and Hemerijck, 2020). The main policy in that regard concerns childcare. High-quality childcare concerns an investment in children that has proven to have positive long-term effects on educational and employment outcomes. Subsidies on childcare may also have more direct employment effects. Due to the associated costs, effective wages fall when parents organise childcare through the market. In the absence of publicly subsidised childcare, some therefore leave the labour market to care for their children. Through expenditures on childcare and early childhood education facilities, governments can stimulate (young) parents to engage in paid employment. The effectiveness of these policies, however, depends on their institutional design. If childcare subsidies lower the price of public childcare below the market clearing price so that public childcare is substituted for private childcare, they can be expected to have little to no effect on employment (Havnes and Mogstad, 2011). In addition to affordability, the availability and quality of the services provided matters as well for these policies to constitute effective social investments (West et al., 2020).

Services for the elderly and frail, such as residential care and home help, operate in a similar manner. While the provision of informal eldercare keeps some people from working entirely, others reconcile work and care by reducing 
working hours or rearranging work schedules. Negative employment effects might therefore be relatively small and tend to hold for women only (Viitanen, 2010; Ciani, 2012). Still, the public provision of these services can be expected to stimulate labour market participation amongst those people that would otherwise provide informal care by enabling them to find a work-life balance (Taylor-Gooby, 2004).

Another policy that has widely been discussed in the literature on social investment concerns education. Both initial education and education during working life can be expected to have a positive effect on the quality of a country's labour force over the medium to long term. A skilled and flexible labour force fosters competitiveness and thereby constitutes the key to productive and economic growth in a rapidly changing world (Lundvall and Lorenz, 2012). This takes place in an increasingly globalised economy in which knowledge becomes obsolete more rapidly than before and where the need for manual labour power has been replaced by the need for skills relevant to the servicebased knowledge economy. In such an economy there is a greater need to invest in education in order to stimulate employment and facilitate transitions between jobs and sectors, which are increasingly being made throughout working careers. Such investments can, on the one hand, be expected to increase attainment and thereby facilitate a skilled labour force with increased chances of finding a job and, on the other hand, improve the quality of instruction and thereby foster human capital development (Nelson and Stephens, 2012).

Last, childbirth may change the preferences of parents with regard to employment. Without maternity and parental leave arrangements especially women are likely to (temporarily) quit employment. While these arrangements are generally characterised by a cash transfer, they can be considered investments because they stimulate employment in the long run. When these leave arrangements are available, people are more likely to utilise this leave period and return to their pre-childbirth job once it ends (Klerman and Leibowitz, 1997). Although parental leave may thereby only delay the return to work or induce mothers that would otherwise find a new job to return to their old job, most empirical studies show that policies that provide paid leave are associated with increases in female employment (Akgunduz and Plantenga, 2013), albeit often resulting in part-time employment (Gutiérez-Domènech, 2005).

Overall, we hypothesise positive effects for the five social investment policies we distinguish. Nevertheless, the way in which these positive effects manifest themselves is likely to differ across the policies considered. Not all policies are equally relevant in terms of their magnitude and the time horizon in which they yield returns on the investment. Early childhood policies and maternity and parental leave are, for example, applicable to young parents only. Likewise, services for the elderly and frail can be expected to yield positive effects 
for people that care for elders only. While ALMPs and education concern a broader population of beneficiaries, their effects might be limited in the short term because the benefits associated with training and schooling are usually reaped over the life-course. Yet, employment effects might be most pronounced for ALMPs, because these policies are directly targeted at stimulating employment, whereas the other policies stimulate employment somewhat indirectly.

\subsection{Institutional complementarity and employment}

An important insight from the social investment literature is that the employment outcomes of policies can be reinforced by providing complementary policies. When introducing the Social Investment Package, the European Commission (2013: 3) acknowledged that the "investment dimension of a specific policy expenditure largely depends on its design features, [its] complementarity with other policies and circumstances in time". Although the complementarity of social investment policies has received increasing attention in recent years, systematic empirical analyses are still scarce.

In the existing literature it has been acknowledged that outcomes of labour market institutions are contingent on cyclical factors and that the effects of specific policies depend on other institutions (Benda et al., 2020). With respect to social investment specifically, most work centres around the theoretical complementarity of policies over the life-course (Dräbing and Nelson, 2017; Hemerijck, 2018). Hemerijck et al. (2016) concerns the only study that empirically tests the complementary effect of expenditures on two social investment policies on employment. Their analysis suggests "some important evidence of institutional complementarities [...] where ALMP appears likely to be most effective in promoting employment particularly where polities also have introduced early-childhood assistance that ease[s] the combination of work and family" (Hemerijck et al., 2016: 48). We expect such complementarities to apply to other policy combinations as well. For instance, eldercare also facilitates the reconciliation of work and family life, thereby stimulating employment. ALMPs could therefore be expected to be more effective in countries that also invest in services for the elderly and frail. Likewise, positive effects of parental leave on employment might be reinforced when countries provide adequate levels of ECEC, thereby easing the transition from temporary leave to work. In addition, the positive effects of education during adolescence on employability might be stronger in countries that invest in high-quality childcare during early childhood.

\subsection{Other factors that affect employment}

Apart from social investment policies, there are other factors that may affect employment rates, notably labour market institutions. First, the lay-off costs associated with employment protection legislation make adjustments to the 
workforce more costly, potentially leading to suboptimal employment levels. Furthermore, high taxes on labour can be expected to have a negative impact on employment by increasing the cost of labour and lowering the returns thereof. Unemployment benefits constitute another relevant factor. Studies on the generosity of unemployment benefits and resulting labour market outcomes suggest that benefit generosity mainly affects the duration of unemployment. Nevertheless, high replacement rates can reduce the scar effects of unemployment, resulting in more employment over the longer run. Last, industrial relations matter as well. Dependent on the bargaining power of trade unions and the centralisation of wage bargaining, different employment effects could be expected (Bradley and Stephens, 2007).

In addition to institutional factors, socioeconomic conditions also play a role. The size of the dependent population is likely to influence the demand for care and education. We distinguish between the dependent population below 15 (youth) and above 64 (aged). Furthermore, employment may be influenced by globalisation, because imports and exports affect the demand for labour. Finally, employment levels depend on the state of the economy and are sensitive to shocks in the demand for labour (Nickell et al., 2005).

\section{Data, measures and method}

\subsection{Variable selection}

The dependent variable of this study is the employment rate expressed as the share of employed people as a percentage of the population (Bradley and Stephens, 2007). Given the possibly disturbing effects of extended periods of schooling and early retirement on employment, this study focuses on the population of prime working age (25-54). Besides, we believe social investments are most likely to affect people within this age group rather than those still in education or just entering the labour market following education (15-24) or approaching retirement (55-64). In our sensitivity analyses we, however, also estimate regressions for the entire population of working age (15-64).

Our independent variables of interest concern effort on five social investment policies. The operationalisation of these variables strongly follows Vandenbroucke and Vleminckx (2011). ${ }^{1}$ We measure effort using disaggregated expenditures, whereby expenditures on a specific programme are corrected for the number of beneficiaries, because expenditures are partly driven by need. Next, these measures are related to GDP per capita in order to allow for comparison across countries and over time. To obtain expenditures on a programme we use the sum of public and mandatory private expenditures available from the OECD's Social Expenditure (SOCX), Labour Market Programmes, and

\footnotetext{
${ }^{1}$ Ronchi (2018) adopts a comparable approach using Eurostat data.
} 
Education and Training databases. As data on the number of beneficiaries of the different policies for the years considered here are not available, we rely on proxies. Table 1 shows the precise expenditure categories and beneficiary groups used.

In operationalising effort on ALMPs we focus on programmes that clearly reflect social investment aspects such as activation and human capital development. We only consider expenditures on programmes associated with Bonoli's (2010) categories 'upskilling' and 'employment assistance', corrected for the number of unemployed. We rely on a rather inclusive definition of early childhood policies that not only includes ECEC, but also other in-kind services targeted at (parents of) young children. It excludes cash transfers such as family allowances. In line with adjustments made to expenditures on ECEC in the SOCX database to account for cross-national differences in the compulsory age of entry into primary education, effort on early childhood policies is corrected for the number of children aged $0-5 .{ }^{2}$ Under services for the elderly and frail we group all in-kind old age and incapacity-related benefits, except for expenditures on rehabilitation services. Since we do not have data on the number of incapacitated individuals due to disability, occupational injury and disease or sickness, these expenditures are corrected for the number of people aged 65 and above. ${ }^{3}$ Expenditures on education cover direct expenditures on primary, secondary and tertiary educational institutions (cf. Busemeyer, 2009). ${ }^{4}$ We use enrolment data to obtain effort per student. As far as we know, no adequate time-series cross-country expenditure data for education during working life are available. Effort on maternity and parental leave comprises cash benefit expenditures on these leave arrangements. Since entitlement is connected to childbirth, we correct these for the number of new-born children.

Expenditure-based measures have some limitations, because they may not capture institutional characteristics of welfare programmes. This caveat notwithstanding, there is relatively little variation in the institutional characteristics determining eligibility for and entitlement to social investment policies like eldercare, childcare, and education. Benefits received through these policies are usually not dependent on past earnings and payments. With regard to education, access to primary and lower secondary schools tends to be universal. For such welfare programmes, social expenditures do constitute an adequate

\footnotetext{
${ }^{2}$ For several countries SOCX does not include expenditures on pre-primary education prior to 1998. To guarantee comparability over time, these expenditures were added and adjusted to refer to children aged $0-5$.

${ }^{3}$ This probably overestimates effort; the denominator does not include the entire beneficiary group. Assuming no structural differences in numbers of incapacitated individuals across countries and over time, this involves no bias.

${ }^{4}$ This covers teacher salaries, investments in school infrastructure and teaching materials, but excludes tuition payments or transfers to students.
} 
TABLE 1. Effort on social investment policies

\begin{tabular}{lllll}
\hline $\begin{array}{l}\text { Active labour market } \\
\text { policies }\end{array}$ & Early childhood policies & Services for the elderly and frail & Education & $\begin{array}{l}\text { Maternity and parental } \\
\text { leave }\end{array}$ \\
\hline $\begin{array}{l}\text { PES and administration; } \\
\begin{array}{l}\text { Training; } \\
\text { Employment incentives; } \\
\text { Start-up incentives }\end{array}\end{array}$ & $\begin{array}{l}\text { Early childhood education and } \\
\text { care; } \\
\text { Home help/accommodation; } \\
\text { Other benefits in kind }\end{array}$ & $\begin{array}{l}\text { Residential care/home-help } \\
\text { services; } \\
\text { Other benefits in kind; }\end{array}$ & $\begin{array}{c}\text { Primary, secondary and } \\
\text { tertiary educational } \\
\text { institutions }\end{array}$ & $\begin{array}{c}\text { Maternity and parental } \\
\text { leave }\end{array}$ \\
\hline Unemployed & Children aged 0-5 & Population aged $\geq 65$ & Students enrolled & Children aged o \\
\hline
\end{tabular}


measure (Jensen, 2011). Furthermore, variation in expenditures across or within countries may not only reflect policy preferences, but may also be the result of different demographic compositions and economic trends. Our operationalisation of effort on social investment policies addresses these demographic and economic aspects. The operationalisation of our control variables, the sources used, and descriptive statistics are presented in the Appendix (Table A1).

\subsection{Methodology}

Following the availability of data our country sample comprises 26 OECD countries. ${ }^{5}$ The time series start in 1990. Since data for some of the independent variables are not available for more recent years, it runs up to 2010. The panel is somewhat unbalanced, predominantly because Central and Eastern European countries are observed for shorter time spans. ${ }^{6}$ To examine the association between effort on social investment policies and employment, time-series cross-section regression analyses are conducted. When examining complementarity the equation is augmented with multiplicative interaction terms.

We employ two different model specifications to analyse the extent to which the development of effort on social investment within countries is associated to their employment rate. The first specification regresses the level of employment on lagged levels of effort on social investment policies, whereas the second uses year-to-year changes. Based on several diagnostic tests (see Appendix 1) we include both country and year fixed effects in our first specification. Our within estimator therefore focuses on variation within countries while controlling for common temporal shocks. Panel-corrected standard errors (PCSE) and Prais-Winsten transformation are used to address spatial correlation of the errors, panel heteroscedasticity and autocorrelation (Beck and Katz, 1995).

As described in the theoretical section, some social investment policies can be expected to have rather direct, short-term impacts, whereas others might reveal their impact over the medium or long term. This is, however, more applicable to redistributive and inequality effects than employment effects (Verbist, 2017). Longer time horizons are particularly relevant for education. In the short run, education might even have a negative impact on the supply of labour as people participate in education instead of on the labour market. Yet, it should be noted that measuring long-term returns is analytically difficult and possibly even impossible (Hemerijck et al., 2016). We therefore focus on short-term effects by using one year lags or first-differences for our independent variables. In our sensitivity analyses we additionally try to capture long-term effects

\footnotetext{
${ }^{5}$ Australia, Austria, Belgium, Canada, the Czech Republic, Denmark, Estonia, Finland, France, Germany, Hungary, Ireland, Italy, Japan, the Netherlands, New Zealand, Norway, Poland, Portugal, Slovakia, Slovenia, Spain, Sweden, Switzerland, the UK, the US.

${ }^{6}$ The panel is characterised by gaps in the 1990 s due to a lack of education expenditure data.
} 
through the use of error-correction models, which are capable of distinguishing short-term transitory and long-term structural effects.

\section{Results}

\subsection{Descriptive results}

Figure A1 shows that there is variation in both employment rates and social investment expenditure across countries and over time. Employment is particularly high (nearly 85\%) in the Nordic countries, Switzerland and the Czech Republic. In Southern European countries and Ireland employment levels have been considerably lower (around 60-70\%). Over time employment rates have risen in practically all countries, albeit to different degrees. In several countries this is predominantly the result of increases in female employment, notably the Netherlands and Ireland. The Czech Republic and Estonia are the only countries that experienced decreases in overall employment. Following the economic crisis, decreases can be observed in nearly all countries after 2008, although there is a lot of variation in the magnitude of these changes.

Expenditures on social investment have, generally, increased over time and are positively associated with employment rates (Figure A2). Table A2 presents effort on the five social investment policies separately. It shows that different types of welfare states prioritise different social investment policies. Across countries efforts on all social investment policies except ALMPs have converged towards a higher level over time. Nevertheless, the data exhibit great variation in terms of the level of effort and developments thereof.

When it comes to effort on ALMPs the Nordic countries are the most generous. Some conservative welfare states such as France and Germany attain similar levels, whilst efforts in liberal and Central Eastern European countries are relatively low. With regard to policies related to care, the Nordic countries again stand out as most generous, whereas efforts by liberal, Mediterranean and Central Eastern European countries are relatively low. Efforts by conservative welfare states are somewhat more generous, but nowhere near those found in Nordic welfare states. Still, there is a lot of variation within these groups of welfare states. Efforts on education exhibit the least variation across countries and this has even decreased over time. This convergence is to a large extent the result of catch-up amongst some of the countries traditionally characterised by relatively low efforts. With respect to maternity and parental leave, the data show that Central and Eastern European countries have overtaken the Nordic countries in terms of resources allocated to every recipient. In recent years, liberal and Mediterranean welfare states have also increased their efforts on this policy, but they still rank amongst countries with relatively low efforts, which also includes most of the conservative welfare states. 


\subsection{Regression analyses}

The results of the regression analyses obtained through our two model specifications are presented in Table 2. For both specifications we first analyse the association between employment and effort on ALMPs and early childhood policies while controlling for labour market institutions and socioeconomic factors. The reason for this is twofold. These policies have figured most prominently within the literature on social investment (Bonoli, 2013; Hemerijck et al., 2016). Besides, the effects associated with these policies can be expected to be larger than those for the other social investment policies that are confined to smaller groups of society (services for the elderly and frail and maternity and parental leave) or require considerably longer time horizons to manifest themselves (education).

Both specifications indicate that effort on social investment-oriented ALMPs is positively associated with employment in the short term (models 1 and 3 ). This association is retained when controlling for additional social investment policies (models 2 and 4 ). More specifically, a one percentage point increase in expenditures on ALMPs per unemployed as a share of GDP per capita is associated with a $0.12-0.13$ percentage point increase in the employment rate. We find no significant correlations for effort on early childhood policies. While other studies found high spending on these policies to be associated with high levels of employment (Nelson and Stephens, 2012), our results suggest that changes in the level of effort are not associated with short-term changes in countries' level of employment. This result could potentially be explained by the fact that (female) labour supply elasticities have decreased due to increasing participation (Blau and Kahn, 2007; Heim, 2007), thereby making the labour force less responsive to changes in effort on early childhood policies.

Subsequently, we augment our model with effort on three other social investment policies. We obtain positive associations for effort on services for the elderly and frail, which is in line with studies describing the manner in which the public provision of these services creates formal care markets that facilitate labour market participation by enabling people that would otherwise provide informal care to find a better work-life balance (Taylor-Gooby, 2004; Simonazzi, 2009). As for effort on early childhood policies, we neither obtain a significant coefficient for effort on education. This is probably due to the short time horizon being studied. In our model specified in levels, we find effort on maternity and parental leave to be negatively associated with employment. Although this contradicts our theoretical expectation, it aligns with findings that more generous and particularly long leave policies decrease labour market attachment and hence reduce returns to work, resulting in labour market exits (Lalive and Zweimüller, 2009). The coefficient is, however, not statistically significant in our model in first-differences. 
TABLE 2. Regressions of employment and effort on social investment policies, 1990-2010

\begin{tabular}{|c|c|c|c|c|}
\hline \multirow{3}{*}{$\begin{array}{l}\text { Dependent variable: } \\
\text { Independent variables: }\end{array}$} & \multicolumn{2}{|c|}{ Employment rate $\left(y_{i, t}\right)$} & \multirow{2}{*}{\multicolumn{2}{|c|}{$\begin{array}{c}\text { Change in } \\
\text { employment rate } \\
\left(\Delta y_{i, t}\right)\end{array}$}} \\
\hline & \multicolumn{2}{|c|}{ Lagged $\left(x_{i, t-1}\right)$} & & \\
\hline & (1) & (2) & (1) & (2) \\
\hline \multicolumn{5}{|l|}{ Effort on social investment policies } \\
\hline Active labour market policies & $\begin{array}{l}0.11^{* * *} \\
(0.01)\end{array}$ & $\begin{array}{l}0.13^{* * *} \\
(0.01)\end{array}$ & $\begin{array}{l}0.10^{* * *} \\
(0.01)\end{array}$ & $\begin{array}{l}0.12^{* * *} \\
(0.01)\end{array}$ \\
\hline Early childhood policies & $\begin{array}{l}-0.03 \\
(0.03)\end{array}$ & $\begin{array}{c}-0.04 \\
(0.04)\end{array}$ & $\begin{array}{c}0.01 \\
(0.04)\end{array}$ & $\begin{array}{l}0.00 \\
(0.05)\end{array}$ \\
\hline Services for the elderly and frail & & $\begin{array}{l}0.17^{* *} \\
(0.07)\end{array}$ & & $\begin{array}{l}0.20^{* *} \\
(0.09)\end{array}$ \\
\hline Education & & $\begin{array}{l}-0.05 \\
(0.05)\end{array}$ & & $\begin{array}{l}-0.00 \\
(0.04)\end{array}$ \\
\hline Maternity and parental leave & & $\begin{array}{c}-0.03^{* *} \\
(0.01)\end{array}$ & & $\begin{array}{c}-0.02 \\
(0.01)\end{array}$ \\
\hline \multicolumn{5}{|l|}{ Labour market institutions } \\
\hline Employment protection legislation & $\begin{array}{l}-0.05 \\
(0.35)_{* * *}\end{array}$ & $\begin{array}{l}-0.05 \\
(0.44)\end{array}$ & $\begin{array}{l}0.76^{* *} \\
(0.37)\end{array}$ & $\begin{array}{c}0.65^{*} \\
(0.38)\end{array}$ \\
\hline Tax wedge & $\begin{array}{l}-0.10^{* * *} \\
(0.03)\end{array}$ & $\begin{array}{c}-0.12^{* * *} \\
(0.04)\end{array}$ & $\begin{array}{c}0.00 \\
(0.03)\end{array}$ & $\begin{array}{c}0.00 \\
(0.04)\end{array}$ \\
\hline Unemployment benefits & $\begin{array}{c}-0.02 \\
(0.03)\end{array}$ & $\begin{array}{c}-0.00 \\
(0.02)\end{array}$ & $\begin{array}{c}0.01 \\
(0.02)\end{array}$ & $\begin{array}{c}-0.01 \\
(0.03)\end{array}$ \\
\hline Trade union density & $\begin{array}{c}0.05 \\
(0.03)\end{array}$ & $\begin{array}{l}0.07^{* *} \\
(0.03)\end{array}$ & $\begin{array}{c}-0.02 \\
(0.05)\end{array}$ & $\begin{array}{c}0.01 \\
(0.06)\end{array}$ \\
\hline Coordination of wage bargaining & $\begin{array}{c}0.14 \\
(0.13)\end{array}$ & $\begin{array}{l}0.20 \\
(0.14)\end{array}$ & $\begin{array}{l}0.22^{* *} \\
(0.09)\end{array}$ & $\begin{array}{l}0.30^{* *} \\
(0.13)\end{array}$ \\
\hline \multicolumn{5}{|l|}{ Socioeconomic factors } \\
\hline Dependent population $<15$ & $\begin{array}{l}-0.59^{* * *} \\
(0.16)\end{array}$ & $\begin{array}{l}-0.71^{* * *} \\
(0.14)^{* * *}\end{array}$ & $\begin{array}{l}-0.08 \\
(0.45)\end{array}$ & $\begin{array}{l}0.12 \\
(0.49)\end{array}$ \\
\hline Dependent population $\geq 65$ & $\begin{array}{l}0.57^{* * *} \\
(0.20)\end{array}$ & $\begin{array}{l}0.54^{* * *} \\
(0.20)\end{array}$ & $\begin{array}{l}0.82^{* * *} \\
(0.30)\end{array}$ & $\begin{array}{l}0.92^{* * *} \\
(0.33)\end{array}$ \\
\hline Capital openness & $\begin{array}{l}0.00 \\
(0.01)\end{array}$ & $\begin{array}{l}-0.00 \\
(0.01)\end{array}$ & $\begin{array}{l}-0.00 \\
(0.00)\end{array}$ & $\begin{array}{l}-0.00 \\
(0.00)\end{array}$ \\
\hline Trade openness & $\begin{array}{l}0.02^{* * *} \\
(0.01)\end{array}$ & $\begin{array}{l}0.02^{* *} \\
(0.01)\end{array}$ & $\begin{array}{l}0.02^{* *} \\
(0.01)\end{array}$ & $\begin{array}{l}0.02^{* *} \\
(0.01)\end{array}$ \\
\hline Real GDP per capita & $\begin{array}{l}0.31^{* * *} \\
(0.06)\end{array}$ & $\begin{array}{l}0.28^{* * *} \\
(0.07)\end{array}$ & $\begin{array}{l}0.52^{\text {**** }} \\
(0.06)\end{array}$ & $\begin{array}{l}0.51^{* * *} \\
(0.06)\end{array}$ \\
\hline Shocks in labour demand & $\begin{array}{l}36.03^{* * *} \\
(8.23)\end{array}$ & $\begin{array}{l}34.87^{* * *} \\
(10.36)\end{array}$ & & \\
\hline Constant & $\begin{array}{l}76.59^{* * *} \\
(5.70)\end{array}$ & $\begin{array}{l}78.53^{* * *} \\
(6.06)\end{array}$ & $\begin{array}{l}-0.52^{* * *} \\
(0.11)\end{array}$ & $\begin{array}{c}-0.45^{* * *} \\
(0.12)\end{array}$ \\
\hline $\begin{array}{l}\text { Number of observations } \\
\text { Adjusted } R \text {-squared }\end{array}$ & $\begin{array}{l}395 \\
0.989\end{array}$ & $\begin{array}{l}339 \\
0.991\end{array}$ & $\begin{array}{c}355 \\
0.472\end{array}$ & $\begin{array}{l}285 \\
0.497\end{array}$ \\
\hline Rho & 0.658 & 0.622 & 0.247 & 0.186 \\
\hline Country fixed effects & Yes & Yes & No & No \\
\hline Year fixed effects & Yes & Yes & No & No \\
\hline
\end{tabular}

Notes: Panel-corrected standard errors in parentheses; ${ }^{*} p<0.1,{ }^{* *} p<0.05,{ }^{* * *} p<0.01$. 


\subsection{Sensitivity analyses}

We conducted extensive sensitivity analyses to examine the robustness of our results. The positive estimate for ALMPs is robust to the exclusion of different variables, whereas estimates for the other policies are generally also replicated (Appendix 2). Additionally, our estimates for the five social investment policies are robust to different operationalisations (Appendix 3). The signs are always in the same direction, except when replacing effort on education by educational attainment (cf. Nelson and Stephens, 2012). Using this alternative measure yields estimates that are in line with the theoretical expectations. We also estimated our preferred model including additional variables to test for omitted variable bias (Appendix 4). All our results are replicated.

Additionally, the use of a different estimation technique (error-correction models) leads to substantively similar results (Appendix 5). Finally, we repeated our analysis by focusing on the population of working age and additionally estimated separate models for men and women, because there is a vast literature that documents differences in labour supply elasticities (Evers et al., 2008). We obtain rather similar results when focusing on these slightly different groups (Appendix 6).

\subsection{Policy complementarities}

Next, we explore the role of policy and institutional complementarities in the assessment of the employment effects of social investment by examining whether the results for the different policies presented in Table 2 are contingent on other policies and welfare state institutions. In the social investment literature, two types of 'institutional complementarities' can be discerned. On the one hand, individual policies can have complementary effects over the life-course. Such temporal complementarities result from the fact that policies positively affect individual opportunities at a certain stage of the life-course and thereby improve the effectiveness of other policies at later stages. On the other hand, policies can complement each other by being targeted toward the same goal. These complementarities have also been referred to as 'life-course synergies' and 'policy synergies' (Hemerijck et al., 2016).

Since our data do not enable us to examine cumulative effects of policies over the life-course, we examine the second type using interaction effects and interpret them with marginal effect plots. ${ }^{7}$ The two different model specifications presented above yield substantively highly comparable results. For our analyses of complementarities we prioritise the model specified in levels. The reason for this is that the employment outcomes of social investment are not simply a function of absolute changes, but also depend on the levels.

\footnotetext{
${ }^{7}$ Marginal effects plots are computed using 95\% confidence intervals. Following conventions, the presented range of the moderating variable excludes the lower and upper five percent of observations.
} 
For instance, in countries with high levels of both spending and employment, increases in the former can be expected to yield smaller employment effects than similar increases in countries characterised by lower levels of spending and employment. We analyse 'policy complementarities' first by testing whether simultaneous efforts on specific policy combinations have a complementary effect on employment. All possible interactions were systematically considered. The results are summarised in Table 3.

We obtain statistically significant interaction effects for just two policy combinations. The other combinations show no signs of policy interdependence. The low prevalence of interdependence might seem surprising, but other scholars obtained comparable results. For a comparable time-series crosssection of countries Hemerijck et al. (2016: 76) find that ALMPs and ECEC "tend to interact positively though not significantly with one another". Similarly, Thévenon's (2016: 483-4) analysis of the interplay between family and care policies with regard to female employment "provide[s] little evidence that policies complement each other ... [although this] lack of statistical significance regarding many of the 'paired interaction terms' does not necessarily mean that institutions do not interact."

Figures 1 and 2 present the marginal effect plots of our significant interactions. Hemerijck et al. (2016) examined the first interaction too and argue that ALMPs are more effective in stimulating employment when countries provide for childcare, thereby enabling employees to reconcile work and family. A similar argument can be assumed to apply to care for the elderly and frail, the second interaction. The figures, however, challenge this argument. The marginal effects of effort on ALMPs on employment are positive in both cases, but get smaller at higher levels of effort on the moderating policies. This suggests that, in the presence of relatively high efforts on early childhood policies and services for the elderly and frail, part of the positive association between ALMPs and employment is captured by these policies, as the provision of care also stimulates employment. Instead of a complementary effect, which would involve upward sloping marginal effects, our results for these two policy combinations suggest diminishing marginal returns.

This does, however, not imply that social investment has no or negative effects in relation to employment. Rather, it implies that for those policies that show no signs of interdependence the returns of this policy are not reinforced when efforts on a complementary policy are increased. Moreover, despite finding diminishing marginal returns, the positive effect of ALMPs is retained in the significant interactions - the marginal effect is always positive.

\subsection{Policy and institutional complementarities across welfare state regimes}

Subsequently we examine whether the observed interdependence of these policies regarding their employment effects is contingent on broader 


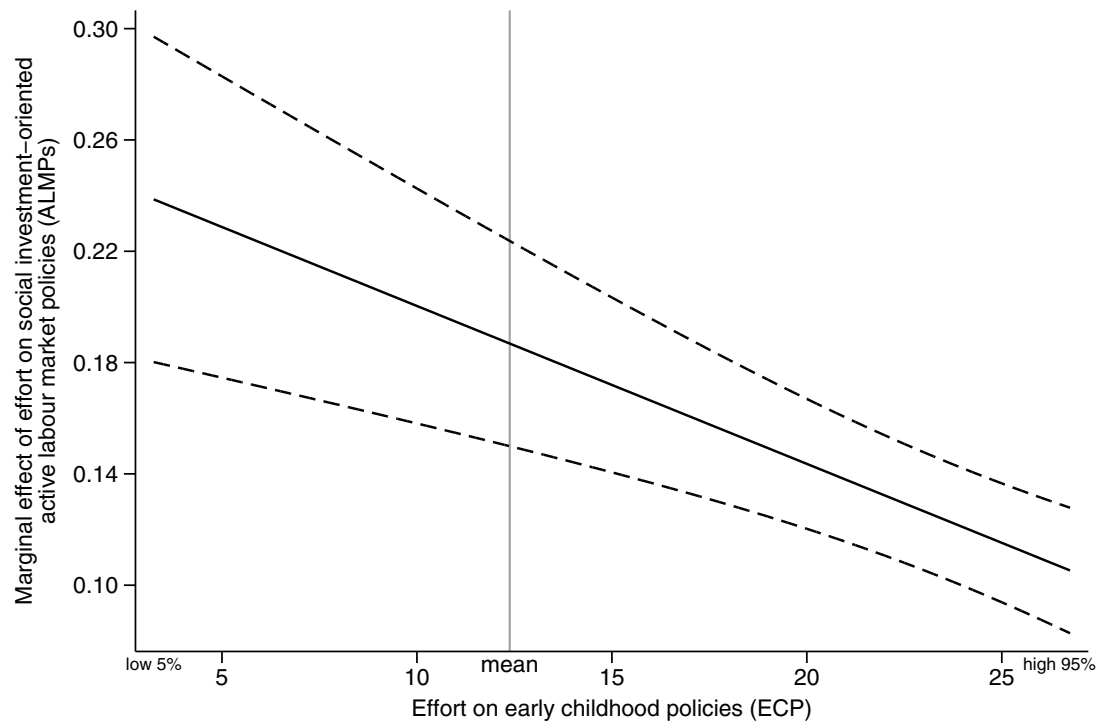

FIGURE 1. Interaction effect of effort on ALMPs and early childhood policies.

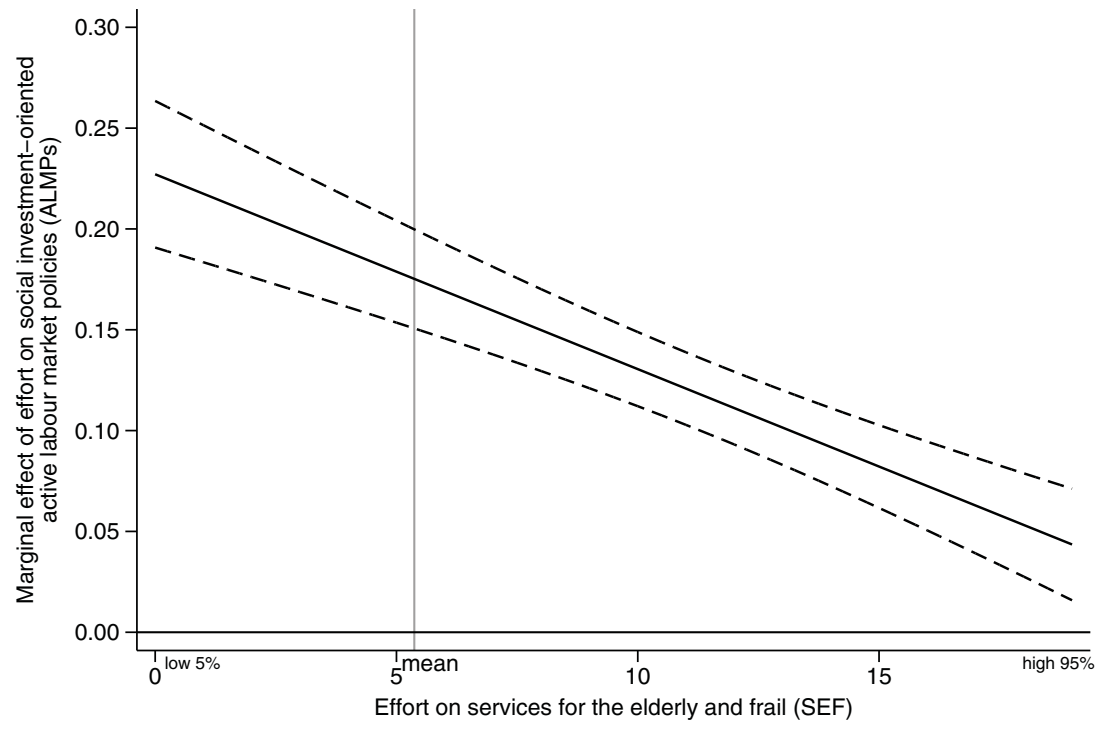

FIGURE 2. Interaction effect of effort on ALMPs and services for the elderly and frail.

configurations of welfare state institutions, because the question whether social investment "delivers the wished-for socio-economic outcomes (...) [depends] on the institutional and economic context of [countries] that greatly differ from each other" (Ronchi, 2018: 16). Distinct regimes have, for instance, been distinguished with regard to the provision and financing of care services for children 

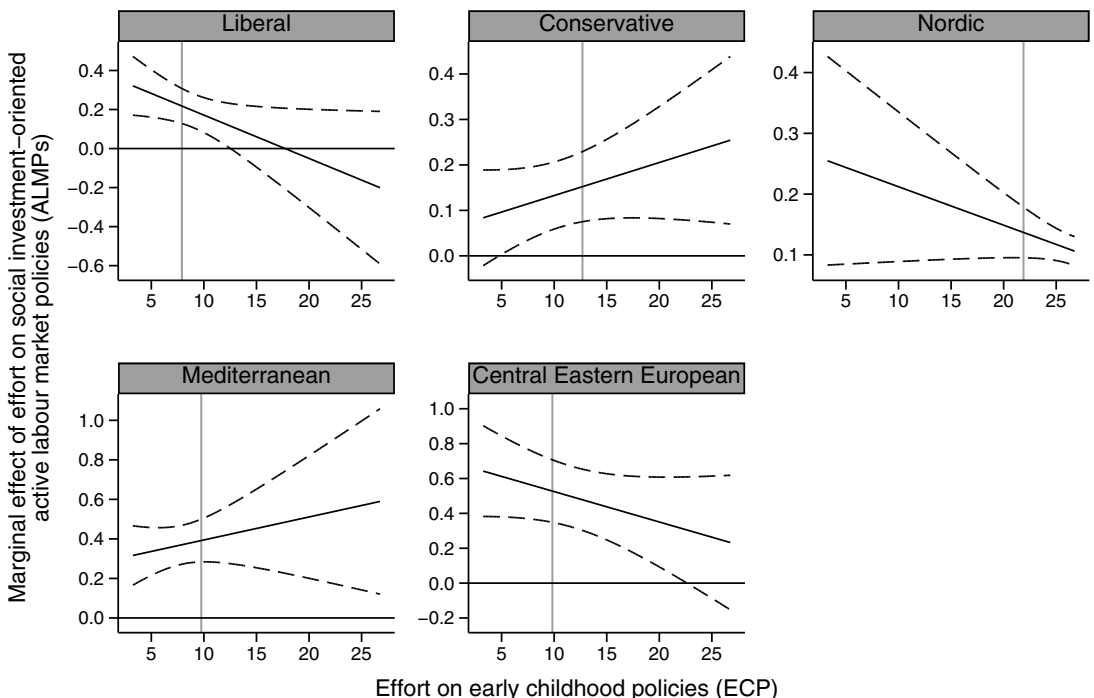

FIGURE 3. Interaction effect of effort on ALMPs and early childhood policies by welfare state regime.

and the elderly, which are associated with different employment models (Simonazzi, 2009).

The idea that the effect of individual policies is contingent on the entire framework of institutions can be traced to Bassanini and Duval (2009) who interact each institution with the overall institutional framework in assessing its effect on unemployment. In a comparable study on the effect of family policies on female employment, Thévenon (2016) examines whether effects differ across groups of countries by interrelating policy variables with regime dummies. We adopt a quite similar approach by interacting our policy interactions with welfare state dummies that capture common characteristics of welfare states belonging to the same regime. Figures 3 and 4 distinguish the interactions presented in Figures 1 and 2 across welfare regimes.

Figure 3 shows that diminishing marginal returns found in Figure 1 hold across most welfare states, except for the conservative and Mediterranean where we do find the complementary effect described by Hemerijck et al. (2016). Conservative welfare states have been characterised by limited availability of childcare (Flynn, 2017), which could therefore explain the observed complementarity, whereas Mediterranean welfare states have been characterised by traditionally low levels of employment that thereby offer stronger potential for social investment policies, especially considering the fact that these countries are characterised by relatively large labour supply elasticities (Bargain et al., 2014). Similarly, Figure 4 shows that the diminishing marginal returns found in Figure 2 hold across all welfare states except the Mediterranean. 

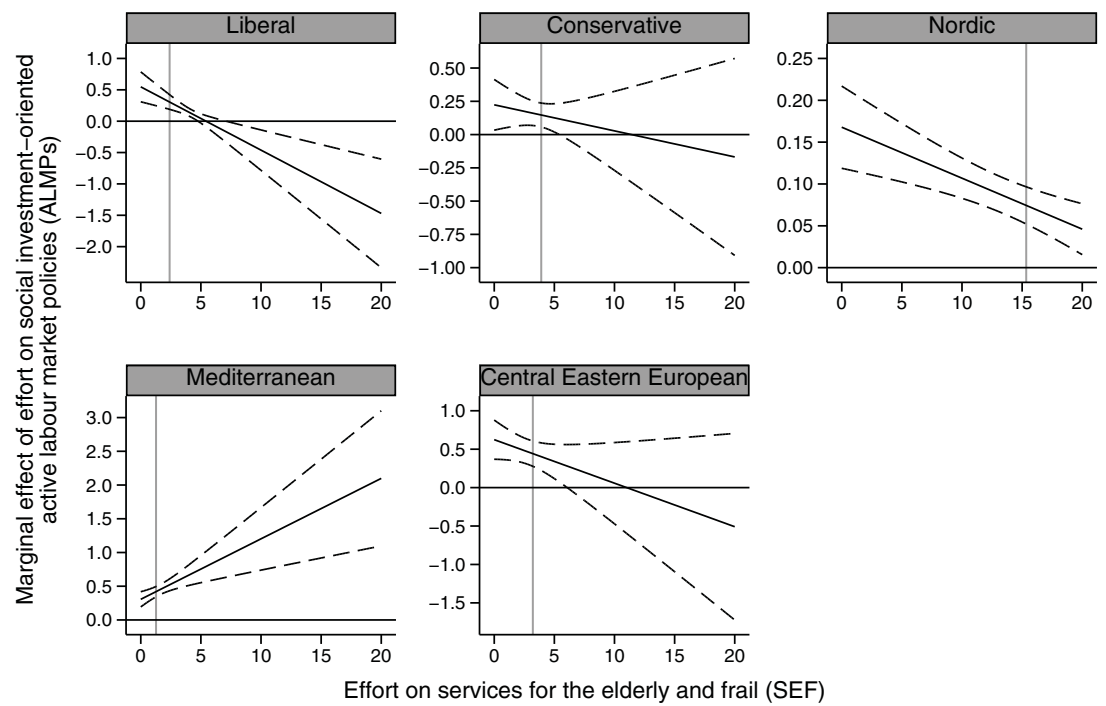

FIGURE 4. Interaction effect of effort on ALMPs and services for the elderly and frail by welfare state regime.

While Nordic welfare states are most generous in the provision of (service-oriented) social investment policies, both figures show diminishing marginal returns for them. At the same time, they have the highest levels of (female) employment and therefore tend to have fairly small labour supply elasticities (Bargain et al., 2014). In such countries, the potential of higher efforts on these policies is therefore limited: hence, the lower likelihood of finding complementary effects. More generally, the figures show that policy interdependence is contingent on the underlying institutions associated with different welfare state regimes.

\section{Conclusion and discussion}

In both policy debates and the academic literature, social investment has been considered an important approach to achieve higher employment rates. Our empirical analysis provides evidence for positive associations between ALMPs and employment, but for other social investment policies we obtain mixed results. To further probe these results, we examine a central argument in the literature that social investment policies are more effective the more they are complemented with other social investment policies. Our results suggest that there is little evidence for such increasing returns. Furthermore, for those policies for which we do observe signs of interdependence, the results do not point at increasing but at diminishing marginal returns. In terms of policy implications, these findings do not render social investment ineffective. Rather, they imply 
that the returns of a policy are not reinforced when efforts on complementary policies are increased.

From a more general and theoretical perspective, our results indicate that to be effective the implementation of social investment requires a more custommade approach as the institutional context varies across countries - something that also follows from our exploration of interdependencies across welfare state regimes. Additionally, it should be noted that social investment not only aims at raising employment, but also the quality thereof. Several studies provide empirical support which shows that social investment policies are capable of improving job quality (Nelson and Stephens, 2012; Dengler, 2019).

The limited support for our hypothesised associations might also signal deficiencies of our methodological approach. Nevertheless, an international comparative approach is probably the most suited to exploit variation in institutional configurations for the analysis of policy and institutional interdependencies with regard to employment outcomes. Yet, such a macro-level analysis comes with a number of limitations. First, several characteristics of social investment policies, such as rules and conditions, are not captured by social expenditure indicators. This could also explain why we find the expected positive association only between ALMPs and employment, whereas singlecountry studies that assess specific policy reforms sometimes do find such effects for the other policies. In this respect, it should be acknowledged that the latter studies are better equipped to identify causal effects than a time-series crosssection analysis. Second, our analysis captures mainly short-term effects, while several policies are likely to require longer time horizons to capture their effect. Third, social investment policies may yield substantial effects for specific groups (e.g. young parents) that are not revealed in analyses of aggregate employment rates. Again, this might explain the divergence between some of our null findings and the results in country-specific studies. A fruitful route for further research seems to be an international comparative analysis at the individual level that moreover provides sufficient leverage to account for institutional complementarity.

\section{Supplementary material}

To view supplementary material for this article, please visit https://doi.org/10. $1017 /$ So0 47279421000386

\section{Acknowledgements}

This study is part of Leiden University's research programme Reform of Social Legislation. Financial support from Institute Gak is gratefully acknowledged. Earlier versions of this paper were presented at the $7^{\text {th }}$ ESPAnet Netherlands/Flanders Researchers Day (Rotterdam, 31 January 2018), the European Commission's Social Situation Monitor Research Seminar 
on Social Investment (Brussels, 29 January 2019) and the KVS New Paper Sessions (The Hague, 24 May 2019). The authors are grateful to all participants and to Anton Hemerijck, Stefano Ronchi, Frank Vandenbroucke, Bruno Palier, Julian Garritzmann, Alexandre Afonso, Philippe van Gruisen, Koen Caminada, Kees Goudswaard, Clare Fenwick and two anonymous reviewers for helpful comments and suggestions.

\section{Competing interests}

We are not aware of any potential conflict of interest.

\section{References}

Ahn, S-H. and Kim, S-W. (2015), Social investment, social service and the economic performance of welfare states. International Journal of Social Welfare, 24(1): 109-119.

Akgunduz, Y.E. and Plantenga, J. (2013), Labour market effects of parental leave in Europe. Cambridge Journal of Economics, 37(4): 845-862.

Armingeon, K. and Bonoli, G. (2006), The Politics of Post-Industrial Welfare States: Adapting post-war social policies to new social risks. London: Routledge.

Bargain, O., Orsini, K. and Peichl, A. (2014), Comparing labor supply elasticities in Europe and the United States: New results. Journal of Human Resources, 49(3): 723-838.

Bassanini, A. and Duval, R. (2009), Unemployment, institutions, and reform complementarities: re-assessing the aggregate evidence for OECD countries. Oxford Review of Economic Policy, 25(1): 40-59.

Beck, N. and Katz, J.N. (1995), What to do (and not to do) with Times-Series Cross-Section Data. American Political Science Review, 89(3): 634-647.

Benda, L., Koster, F. and Van der Veen, R. (2020), Activation is not a panacea: active labour market policy, long-term unemployment and institutional complementarity. Journal of Social Policy, 49(3): 483-506.

Blau, F. and Kahn, L. (2007), Changes in labor supply behavior of married women: 1980-2000. Journal of Labor Economics, 25(3): 393-438.

Bonoli, G. (2010), The Political Economy of Active Labor-Market Policy. Politics \& Society, 39(4): 435-457.

Bonoli, G. (2013), The Origins of Active Social Policy: Labour Market and Childcare Policies in a Comparative Perspective. Oxford: Oxford University Press.

Bonoli, G. and Natali, D. (eds.) (2012), The Politics of the New Welfare State. Oxford: Oxford University Press.

Bouget, D., Frezer, H., Marlier, E., Sabato, S. and Vanhercke, B. (2015), Social Investment in Europe; A Study of national policies. Brussels: European Commission.

Bradley, D. H. and Stephens, J.D. (2007), Employment Performance in OECD Countries; A Test of Neoliberal and Institutionalist Hypotheses. Comparative Political Studies, 40(12): 1486-1510.

Busemeyer, M.R. (2009), Social democrats and the new partisan politics of public investment in education. Journal of European Public Policy, 16(1): 107-126.

Card, D., Kluve, J. and Weber, A. (2017), What Works? A Meta-Analysis of Recent Active Labor Market Program Evaluations. Journal of the European Economic Association, 16(3): 894-931.

Ciani, E. (2012), Informal adult care and caregivers' employment in Europe. Labour Economics, 19(2): 155-164.

Dengler, K. (2019), Effectiveness of Active Labour Market Programmes on the Job Quality of Welfare Recipients in Germany. Journal of Social Policy, 48(4): 807-838.

Dräbing, V. and Nelson, M. (2017), Addressing Human Capital Risks and the Role of Institutional Complementarities. Hemerijck, A. (ed.), The Uses of Social Investment. Oxford: Oxford University Press. 
Esping-Andersen, G. (ed.) (2002), Why We Need a New Welfare State. Oxford: Oxford University Press.

European Commission. (2013), Towards Social Investment for Growth and Cohesion Including Implementing the European Social Fund 2014-2020. Brussels.

Evers, M., De Mooij, R. and Van Vuuren, D. (2008), The Wage Elasticity of Labour Supply: A Synthesis of Empirical Estimates. De Economist, 156(1): 25-43.

Flynn, L. (2017), Childcare markets and maternal employment: A typology. Journal of European Social Policy, 27(3): 260-275.

Garritzmann, J. L., Busemeyer, M. R. and Neimanns, E. (2018), Public demand for social investment: new supporting coalitions for welfare state reform in Western Europe? Journal of European Public Policy, 25(6): 844-861.

Gutiérez-Domènech, M. (2005), Employment after motherhood: a European comparison. Labor Economics, 12(1): 99-123.

Havnes, T. and Mogstad, M. (2011), Money for nothing? Universal child care and maternal employment. Journal of Public Economics, 95(12): 1455-1465.

Heim, B. (2007), The incredible shrinking elasticities: Married female labor supply, 1978-2002. Journal of Human Resources, 42(4): 881-918.

Hemerijck, A. (2018), Social Investment as a policy paradigm. Journal of European Public Policy, 25(6): 810-827.

Hemerijck, A., Burgoon, B., Di Pietro, A. and Vydra, S. (2016), Assessing Social Investment Synergies (ASIS). Brussels: Directorate-General for Employment, Social Affairs and Inclusion.

Jensen, C. (2011), Less Bad than its Reputation: Social Spending as a Proxy for Welfare Effort in Cross-national Studies, Journal of Comparative Policy Analysis: Research and Practice, 13(3): 327-340.

Klerman, J. and Leibowitz, A. (1997), Labor supply effects of state maternity leave legislation. Blau, F. and Ehrenberg, R. (eds.), Gender and Family Issues in the Workplace. New York: Russell Sage Foundation.

Kuitto, K. (2016), From social security to social investment? Compensating and social investment welfare policies in a life-course perspective. Journal of European Social Policy, 26(5): 442-459.

Kvist, J. (2013), The Post-crisis European Social Model: Developing or Dismantling Social Investments? Journal of International and Comparative Social Policy, 29(1): 91-107.

Lalive, R. and Zweimüller, J. (2009), How Does Parental Leave Affect Fertility and Return to Work? Evidence from Two Natural Experiments. Quarterly Journal of Economics, 124(3): 1363-1402.

Lundvall, B.-A. and Lorenz, E. (2012), Social investment in the globalizing learning economy: A European perspective. Morel, N., Palier, B. and Palme, J. (eds.), Towards a Social Investment Welfare State? Ideas, Policies and Challenges. Bristol: Policy Press.

Midgley, J. (1999), Growth, Redistribution, and Welfare: Toward Social Investment. Social Service Review, 73(1): 3-21.

Morel, N., Palier, B. and Palme, J. (eds.) (2012), Towards a Social Investment Welfare State? Ideas, Policies and Challenges. Bristol: Policy Press.

Nelson, M. and Stephens, J.D. (2012), Do social investment policies produce more and better jobs? Morel, N., Palier, B. and Palme, J. (eds.), Towards a Social Investment Welfare State? Ideas, Policies and Challenges. Bristol: Policy Press.

Nickell, S., Nunziata, L. and Ochel, W. (2005), Unemployment in the OECD since the 1960s. What Do We Know? Economic Journal, 115(500): 1-27.

Plavgo, I. and Hemerijck, A. (2020), The social investment litmus test: Family formation, employment and poverty. Journal of European Social Policy. DOI: https://doi.org/10. $1177 / 0958928720950627$.

Ronchi, S. (2018), Which Roads (if any) to Social Investment? The Recalibration of EU Welfare States at the Crisis Crossroads (2000-2014). Journal of Social Policy, 47(3): 459-478. 
Simonazzi, A. (2009), Care regimes and national employment models. Cambridge Journal of Economics, 33(2): 211-232.

Taylor-Gooby, P. (ed.) (2004), New Risks, New Welfare: The Transformation of the European Welfare State. Oxford: Oxford University Press.

Taylor-Gooby, P., Gumy, J.M. and Otto, A. (2015), Can 'New Welfare' Address Poverty through More and Better Jobs? Journal of Social Policy, 44(1): 83-104.

Thévenon, O. (2016), Do 'institutional complementarities' foster female labour force participation? Journal of Institutional Economics, 12(2): 471-497.

Vandenbroucke, F. and Vleminckx, K. (2011), Disappointing poverty trends: is the social investment state to blame? Journal of European Social Policy, 21(5): 450-471.

Van Vliet, O., Bakker, V. and Van Doorn, L. (2021), From Social Protection to Social Investment: European Responses to Globalization, Technological Change, Labour Market Flexibilization, and Migration. Fischer, G. and Strauss, R. (eds.) Europe's Income, Wealth, Consumption, and Inequality. Oxford: Oxford University Press.

Van Vliet, O. and Wang, C. (2015), Social Investment and Poverty Reduction: A Comparative Analysis across Fifteen European Countries. Journal of Social Policy, 44(3): 611-638.

Verbist, G. (2017), Measuring Social Investment Returns. Hemerijck, A. (ed.), The Uses of Social Investment. Oxford: Oxford University Press.

Viitanen, T.K. (2010), Informal Eldercare across Europe: Estimates from the European Community Household Panel. Economic Analysis and Policy, 40(2): 149-178.

West, A., Blome, A. and Lewis, J. (2020), What characteristics of funding, provision and regulation are associated with effective social investment in ECEC in England, France and Germany? Journal of Social Policy, 49(4): 681-704. 